\title{
Hematopoetik Kök Hücre Transplantasyonu Sonrası Yaşam: Hemşirenin Bakım Rolü
}

\author{
Hava KARA ${ }^{1}$, Fatma ARIKAN ${ }^{2}$ \\ 1 Akdeniz Üniversitesi Hastanesi, Antalya. \\ 2 Akdeniz Üniversitesi Hemşirelik Fakültesi, İç Hastalıkları Hemşireliği Anabilim Dalı, Antalya.
}

\section{ÖZET}

Hematopoetik kök hücre transplantansyonu (HKHT), yüksek riskli, ancak iyileștirici bir tedavidir. HKHT'de her aşama önemli olmakla birlikte tedavi sürecindeki geçişler bireyin sağ kalımında anahtar rol oynamaktadır. HKHT hastalarında taburculuk sonrası süreçte takip ve yönetim zordur. Birey, nakil merkezinden sonra çeşitli sorunlarla karşı karşıyadır. HKHT taburculuk sonrası süreçte bireylerin en sık karşılaştı̆̆ geç komplikasyonlar; graft versus host hastalığı (GVHD), enfeksiyöz komplikasyonlar, yorgunluk, sosyal uyumsuzluk (cinsellik, işe dönüş), psikolojik sıkıntı (depresyon, anksiyete) ve sekonder malign hastalıklardır. Birey maruziyetlerine dayalı olarak tarama ve önleyici yaşam boyu takibi gerekli olan bu özel grubun değerlendirilmesinde hemşirelik bakımı, bireye ve aileye rehberlik etmek ve tavsiyede bulunmak için en iyi konumdadır. Bireylerin uzun vadeli sağlığını korumak için hasta merkezli ve multidisipliner koordineli hemşirelik bakımı sağlanmalıdır. Bu derlemenin amacı, hematolojik maligniteleri olan yetişkinler için HKHT taburculuk sonrası yaşamla ilgili güncel literatürün kapsamlı genel görünümünü sağlamaktır ve taburculuk sonrası hemşirelik bakımını vurgulamaktır.

Anahtar Kelimeler: Hematopoetik Kök Hücre Transplantasyonu. Transplantasyon Sonrası Yaşam. Hemşire. Bakım.

Life after Hematopoietic Stem Cell Transplantation: Care Role of Nurses

\begin{abstract}
Hematopoietic stem cell transplantation (HSCT) is a high risk but healing treatment. Although every stage is important in HSCT, transitions in the treatment process play a key role in survival. In HSCT patients, follow-up and management are difficult in the post discharge period. After from the transplant center, faces complications that may occur. The most common late complications encountered by HSCT in the post-discharge period are; graft versus host disease (GVHD), infectious complications, fatigue, social maladjustment (sexuality, return to work), psychological distress (depression, anxiety) and secondary malign diseases. Nursing care is in the best position to guide and advise the individual and the family in the assessment of this special group, which requires screening and preventive lifelong follow-up based on individual exposures. Patient-centered and multidisciplinary coordinated nursing care should be provided to protect the long-term health of individuals. The purpose of this review is for adults with hematological malignancies, HSCT related to life after discharge to provide a comprehensive overview of the current literatüre and emphasizing nursing care after discharge.
\end{abstract}

Key Words: Hematopoietic Stem Cell Transplantation. Life After Transplantation. Nurse. Care.

Hematopoetik kök hücre transplantansyonu (HKHT); hematolojik maligniteleri tedavide kullanılan, ${ }^{1,2}$ birçok ekiple ve servisle etkileşimde bulunulan, disiplinli yaklaşım gerektiren yüksek riskli bir tedavidir.,

Geliş Tarihi: 16.Aralık.2020

Kabul Tarihi: 29.Mart.2021

Uzm. Hem. Hava KARA

Akdeniz Üniversitesi Hastanesi,

Antalya.

Tel: 02422496000

E-posta: havakara@akdeniz.edu.tr

Yazarların ORCID ID Bilgisi:

Hava KARA: 0000-0002-0534-5820

Fatma ARIKAN: 0000-0003-048-1903
HKHT hastaları, komplikasyon sayısı, artan mortalite, uzun rehabilitasyon süreci, bağışıklık sisteminin karmaşıklığ 1 ve yoğun prosedür nedeniyle onkoloji hastaları arasında en karmaşık popülasyondur. ${ }^{5,6}$ Hastalar birçok aşamadan oluşan kritik süreçlerden geçerler ve özellikle geçiş dönemlerinde yüksek risk altındadırlar. ${ }^{7} \mathrm{Bu}$ süreç ön kabul, hazırlık rejimleri, hastaneye yatma, taburcu olma, nakil sonrası bakım ve hayatta kalma gibi evrelerden oluşmaktadır. ${ }^{7,8}$

Hastaneden taburcu olma ve taburculuk sonrası süreç hastaların sonuçlarını etkileyen ve bakımın sürekliliğinde kritik bir noktadır. ${ }^{5}$ Geçişler kötü uygulandığında bakım kalitesinin ve hasta güvenliğinin olumsuz etkilendiği aktarılmaktadır., ${ }^{7,9}$ Nakilden sonraki ilk y1l genel sağ kalım, \%22 ila \%90 arasında değişmektedir. ${ }^{10}$ Transplantasyondan sonraki süreçte ilk haftalar 
ve aylar, graft versus host hastalığ 1 (GVHD), enfeksiyon, beslenme sorunları, gastro intestinal komplikasyonlar, anksiyete, depresyon ve nüks gibi geri dönüşlerle seyredebilmektedir. ${ }^{5,10}$ Yeni ortaya çıkan komorbiditeler, hem yaşam kalitelerini düşürür hem de genel popülasyonla karşılaştırıldığında, transplantasyonun 15-20 yıl içinde mortalite riskini \%20 arttırır., Transplantasyondan sonra en az 30 y1l boyunca mortalite oranının, 5 yıllık nüks olmayan sağ kalanlarda genel popülasyona göre 4 ila 9 kat daha yüksek olduğu bildirilmiştir. ${ }^{12}$ Ayrıca uzun süreli rehabilitasyon ve ölüm riski, hastaların çaresizlik ve yoğun korku yaşamalarına neden olmaktadır. ${ }^{3,6}$ Hemşireler, transplantasyon bakımının gidişatındaki geçiş ve tedavi aşamalarında, bu sürece adım atmada, hastaların ve bakım verenlerin eğitim gereksinimlerini karşılanmasında benzersiz bir role sahiptirler. ${ }^{7,13} \mathrm{Bu}$ derlemenin amac1, hematolojik maligniteleri olan yetişkinler için otolog ve allogenik HKHT taburculuk sonrası yaşamla ilgili güncel literatür doğrultusunda uygulanabilecek taburculuk sonrası hemşirelik bakımına dikkat çekmektir.

\section{Taburculuk Sonrası Süreç}

HKHT hastaları, nakil işlemini "tedavi için son seçenek" olarak düşünürler, bu nedenle belirsizlik ve nüks korkusu üst düzeydedir. ${ }^{10,13} \mathrm{Bu}$ süreçte hastaların farklı baş etme tarzları olduğu bilinmektedir. Negatif başa çıkma tarzı, hastaların yaşam kalitesini ve prognozunu bozarken, pozitif başa çıkma tarzı hastaların psikolojik baskısını hafifletebilmektedir. ${ }^{6}$

Süreç içinde hastalar; kronik graft versus host hastal1ğ1, endokrin, kardiyovasküler veya nörokognitif hastalıklar gibi nakil ile ilgili komplikasyonların yanı sıra, yorgunluk, iştah değişiklikleri, fiziksel güç değişiklikleri, depresyon, duygusal sıkıntı, düşük sosyal destek benzeri sorunlarla da karşılaşmaktadırlar. ${ }^{3,9,10,14}$ Kurosawa ve ark. $(2016)^{15}$ yaptıkları çalışmada otolog HKHT'den sonra hastaların \%80'inden fazlasının taburcu olduktan sonra doğrudan birincil hastalığın neden olduğu fiziksel sorunlarla karşılaştığını ve \%90'ının uzun dönemli bakıma ihtiyaç duyduklarını bildirmişlerdir. Crooks ve ark. $(2014)^{3}$ yaptıkları çalışmada taburcu olan hastaların \%62'sinin fiziksel problemlerinin devam ettiğini ortaya koymuşladır. Veriler taburculuk sonrasında bakımın öneminin yadsinamaz olduğunu göstermektedir. ${ }^{6}$ HKHT hastaları, yakın denetim ve bakım altında olmalıdır ${ }^{2}$ ve uzun süreli takipleri mutlaka yapılmalıdır. ${ }^{12}$

Majhail ve ark. (2012) ${ }^{16}$ tarafindan Uluslararası Kan ve Kemik İliği Nakli Araştırma Merkezi, Amerikan Kan ve Kemik İliği Nakli Derneği (ASBMT), Avrupa Kan ve Kemik İliği Nakli Grubu (EBMT), AsyaPasifik Kanı ve İliği Nakli Grubu (APBMT), Avustralya ve Yeni Zelanda Kemik İliği Nakli Derneği (BMTSANZ), Doğu Akdeniz Kan ve İliği Nakli Grubu (EMBMT) ve Brezilya Kemik İliği Nakli Derneği (SBTMO) adına nakil hastaları için bir kılavuz geliş- tirmişlerdir. Yayınlanan bu kılavuz, nakilden sonra en az 6 ay hayatta kalan otolog ve allojenik kök hücre nakli hastaları için tarama ve önleyici tedbirler üzerinde fikir birliği sağlamaktadır. Otolog ve allojenik HKHT hastalarında geç komplikasyonların taranması ve önlenmesi için 2012 uluslararası konsensüs kılavuz özeti Tablo I'de verilmiştir. ${ }^{16-18}$

HKHT sonrası başlayan sürecin her adımında hekim, hemşire ve diğer ekip üyeleri multidisipliner ekip yaklaşımıyla hastaya yaklaşmalıdır. Hekim öncülügünde başlayan ve devam eden süreçte; immünite, oküler, oral ve solunum gibi sistemlerde geç komplikasyonların önlenmesine yönelik GVHD’de daha sık olmak üzere, rutinde 6 ay, 12 ay ve yıllık taramalarla hasta takibi yapılmalıdır (Tablo I). Hastanın durumuna göre hekim bu süreyi kısaltabilir ${ }^{17,18}$ Bununla birlikte kök hücre nakli yapılan tüm hastalara uygulanacak nakil sonrası bakımı yönlendiren standart bir araç yoktur. Her hasta bireyseldir bu nedenle bireyselleştirilmiş bir bakım planın oluşturulması gerekir. ${ }^{17,19,20}$ Ekibin her bir üyesi aşamaları ve basamakları hastaya göre biçimlendirmelidir. ${ }^{16} \mathrm{Bu}$ doğrultuda; uzun vadeli takip araçlarının çok yönlü anlayışla yeniden şekillenmesiyle hastadaki sorunlar erken dönemde belirlenecektir, erken müdahale olasılığı arttırılmış olacaktir. $^{12}$

\section{Taburculuk Sonrası Görülen Semptomlar ve Semptomlara İlişkin Hemşirelik Bakımı}

HKHT sonrası dönemde nakilden aylar, yıllar sonra ortaya çıkan tıbbi sorunlar; otoimmün bozukluklar ve hematolojik komplikasyonlar, solunum yolları ve akciğer ile ilgili hastalıklar, kardiyovasküler hastalıklar, oküler komplikasyonlar, kas-iskelet sistemi sorunları ve kemik mineralizasyon bozuklukları, oral mukoza ve diş sorunları, genitoüriner sistem sorunlar, gastrointestinal ve hepatik komplikasyonlar (GVHD), metabolik problemler, sekonder maligniteler ve psikososyal sorunlar olarak görülür. ${ }^{18,21,22}$

\section{1- Graft Versus Host Hastalığı (GVHD) ve Hemşi- relik Bakımı}

HKHT sonrası dönem, bireylerin \%30'u ila \%40'inı etkiler, önemli morbiditeye ve mortaliteye neden olur. HKHT'nin bu geç komplikasyonu, mukokutanöz, oküler, gastrointestinal, hepatik, kas-iskelet sistemi ve immünolojik bozukluklar dahil olmak üzere heterojen ve çok sistemli klinik belirtilere sahiptir. ${ }^{23,24}$ GVHD'de cilt (döküntü, doku, hareketlilik) ve sıv1 elektrolit değerlendirmesi, ağız bakımı, beslenme, eklem hareketliliği ve tedavi komplikasyonlarına odaklanılmalıdır. ${ }^{25}$ Mitchell ve ark. $(2010)^{23}$ tarafindan yapılan çalışmada kronik GVHD yaşayan 100 hastada fonksiyonel performans, fiziksel fonksiyon, rol ve genel sağlık alanlarında yaklaşık \%28'lik bir azalma olduğunu bildirilmiştir. GVHD yaşayan hastalar; cilt bakımı, eğitim, ilaç yönetimi bakım koordi- 


\section{Kök Hücre Transplantasyonunda Hemşirenin Rolü}

nasyonu hususlarında ve tedavinin sürdürülmesinde temel hemşirelik bakımının ötesinde bilgilerle ve becerilerle desteklenmelidir. ${ }^{25} \mathrm{Bu}$ kapsamda;

$\checkmark$ GVHD risk faktörleri hastaya tanımlanmalıdır ve hastanın riski azaltmak için alabileceği önlemler açıklanmalıdır. GVHD'nin belirti ve semptomlarını değerlendirmek için kullanılan tanı testlerinin amacı açıklanmalıdır. GVHD'yi yönetmek için hastada kullanılan tedavi yaklaşımının amacı, zamanlaması ve yan etkileri belirtilmelidir ve takip edilmelidir.

$\checkmark$ Hastaya GVHD'nin komplikasyonlarını en aza indirecek önlemler açıklanmalıdır. Temelde sorunlar değerlendirilmelidir, izlenmelidir ve tespit edilmelidir. ${ }^{26,27}$

\section{Cilt Bütünlüğünün Korunmasında Hemşirelik Bakımı}

Cildin herhangi bir lezyon ve/ veya enfeksiyon açısından günlük takibi yapılmalıdır. Cildin losyonlarla nemlendirilmesi sağlanmalıdır ve duruma göre topikal ajanlar kullandırılmalıdır. Sklera muayenesi yapılmalidır. Hasta dehidratasyon açısından takip edilmelidir. Cilt biyopsisi ile ilgili hasta ve aile eğitimi verilmelidir. Hastaya ve aileye doğrudan güneş 1şığından kaçınmanın gerekliliği, açık havada güneş kremi ve koruyucu kıyafet kullanmanın önemini öğretilmelidir. Açık cilt lezyonu olan hastalarda sekonder enfeksiyonu en aza indirmek için antimikrobiyal profilaksi düşünülmelidir ve değerlendirilmelidir. ${ }^{24,28}$

\section{Anoreksia/ Bulantı / Kusma Durumlarında Hemşi- relik Bakımı}

İştahsızlık tanımlanmalıdır. Hastanın diyeti hastaya uygun düzenlenir, duruma göre değiştirilir ve takibi yapılır. Hastaya az az, sık beslenmenin önemi anlatılır ve hidrasyonu sağlanır. Sakin, iyi havalandırılmış ortam önerilir. Tat değişiklikleri, erken tokluk, bulantı veya mukozit durumlarında hastaya kullanılacak yaklaşımlar anlatılmalıdır. Duruma göre antiemetikler kullandırılmalıdır. ${ }^{26}$

\section{Diarede Hemşirelik Bakımı}

Diare tanımlanmalıdır, hastanın ilaçları ve diyeti gözden geçirilmelidir. Günlük aldığı çıkardığı, kilo takibi, sıvı-elektrolit, dehidratasyon ve diare sıklığı/ miktarı takibi yapılmalıdır. Hastanın yeterli hidrasyonu sağlanmalıdır. Laktoz içeren tüm ürünler ve yüksek osmolar gıda takviyeleri durdurulmalıdır. Hastanın kafein ve alkolden kaçınması ve az yağlı, az lifli diyet tüketmesi sağlanmalıdır. Diarenin sıklığı ve şiddetine göre loperamid, tincture of opium, oktreotid, beklometazon kullanılmalıdır. Perirektal cilt bütünlüğü değerlendirilmelidir ve uygun losyonlar kullanılmalıdır. ${ }^{26,29}$

Oral ilaçların emilimi bozabileceğinden kandaki ilaç seviyeleri düzenli izlenmelidir. Endoskopi konusunda hasta ve aile eğitimi verilmelidir. ${ }^{26}$

\section{Karaciğer Fonksiyon Durumunun Korunmasında Hemşirelik Bakımı}

Karaciğer fonksiyon testleri, siklosporin, takrolimus gibi ilaçların seviyeleri düzenli aralıklarla izlenmelidir. Karaciğer biyopsisi konusunda hasta ve aile eğitimi verilmelidir. Hastanın ilaca bağlı araç sürerken ortaya çıkabilecek görmede değişiklik, koordinasyon kaybı gibi problemleri tanımlaması sağlanarak hasta ile birlikte değerlendirilmelidir. ${ }^{26,28}$

\section{Sıvı ve Elektrolit Anormalliklerinde Hemşirelik Bakımı}

Hastanın günde 2-3 lt arasında hidrasyonu sağlanmalıdır. Kilo, aldığ 1 çıkardığı, sıvı-elektrolit ve dehidratasyon veya aşırı yüklenme takibi yapılmalıdır. ${ }^{25,26}$

\section{Malnütrisyonda Hemşirelik Bakımı}

Beslenme durumunu düzenli, kapsamlı şekilde uzun süreli değerlendirilmelidir ve yönetilmelidir. GVHD diyeti uygulanmalıdır. Gerektiğinde kalori sayımları,sıvı alımı izlenmelidir. Tat değişiklikleri, kserostomi, erken tokluk, bulantı/ kusma, mukozit, özofajit gibi durumlarda yaklaşımlar anlatılmalıdır. Hastanın durumuna göre protein alımı, kalsiyum, D vitamini takviyesi arttırılmalıdır; demir içermeyen çoklu folik asit, çinko ve $C$ vitamini takviyesi düşünülmelidir. ${ }^{26,30}$

\section{Ağrıda Hemşirelik Bakımı}

Ağrının / rahatsızlığın hasta tarafından sözlü ifade edilmesi sağlanmalıdır. Günlük yaşamda aktivitelerini hangi ölçüde etkilediği belirlenmelidir. Ağrı şiddeti skala kullanılarak ölçülmelidir. Ağrının türüne göre (karın krampları, kas ağrıları, oral mukozal ağrı veya cilt ağrısı) yaklaşımlar hastaya ve aileye öğretilmelidir. Hastanın durumuna göre destekleyici müdahaleler ve/ve ya analjezikler düşünülmelidir. ${ }^{26,31}$

\section{2- Enfeksiyöz Komplikasyonlar ve Hemşirelik Bakımı}

Enfeksiyöz komplikasyonlar sitopeni, immünsüpresyon nedeniyle HKHT'den sonraki dönemde sık görülür. ${ }^{16}$ Hücresel ve humoral bağışıklık sistemlerinin yeterli şekilde yeniden oluşturulması, otolog HKHT'den sonraki 6-12 ay içinde ortaya çıkar. Allojenik HKHT alıcılarında 2 yıl veya daha uzun sürer. Enfeksiyonlar hem otolog hem de allojenik HKHT alıcılarında geç morbiditeyi ve mortaliteyi artırmaktadır. $^{18} \mathrm{Bu}$ açıdan enfeksiyon önleyici ve kanıta dayalı uygulamaların desteklenmesi; transplantasyon sonrası erken dönemde mortalitenin azaltılmasinda etkilidir. ${ }^{21}$

Enfeksiyon riskini en aza indirecek hastaya ve aileye öz bakım stratejileri ve tedbirler öğretilmelidir. Günlük rutinler içinde maske kullanımı, evcil hayvanlarla temas, gün 1şığına çıkma, toprakla uğraşma gibi durumlarda hastanın kendisini koruması için tüm önlem- 
ler anlatılmalıdır, hastanın takibi sağlanmalıdır. Özellikle GVHD hastaları için influenza ve pneumococcus'a karşı aşılama düşünülmelidir. ${ }^{26,28,32}$

\section{3- Yorgunluk ve Hemşirelik Bakımı}

Yorgunluk, HKHT hastalarında en sık görülen komplikasyonlardandır. ${ }^{1,17}$ Baer ve ark. (2020) ${ }^{33}$ tarafindan yapılan çalışmada HKHT hastalarında yorgunluk en s1k ve şiddetli görülen semptom olarak bulunmuştur. Transplantasyondan sonraki beş yıl içinde hastaların \%41'inde şiddetli yorgunluk yaşandığı, sağ kalım hastalarının yorgunluk düzeyinin zaman geçtikçe azalacağı bildirilmiştir. ${ }^{1}$ Yorgunluk, günlük yaşamı olumsuz yönde etkiler, hastanın günlük aktiviteleri gerçekleştirme kapasitesini azaltır, zihinsel konsantrasyonu, sosyal işlevselliği ve sağlıkla ilişkili yaşam kalitesini bozar. ${ }^{34}$ Bilgilendirici materyal ve yorgunluk yönetimi eğitimi veren hemşireler, hastaları ile işbirli$\breve{g i}$ halinde bu sorunu başarılı bir şekilde çözümleyebilmektedirler. $^{17}$

Değerlendirme ve tedavi için fizik tedaviye ve mesleki terapiye başvurulmalıdır. Fiziksel egzersiz hastaya göre planlanmalıdır. Hastada kas güçsüzlüğü varsa, hasta kas güçlendirme sağlayan odak egzersizlerine teşvik edilmelidir. Farkındalık, ilerleyici kas gevşemesi ve hipnoz gibi çeşitli tamamlayıcı terapilere yönlendirmelidir. Hasta günlük yaşam ve kendi bakım aktivitelerinde maksimum bağımsızlığını korumaya teşvik edilmelidir. ${ }^{26,35}$

\section{4- Sosyal Uyumsuzluk ve Hemşirelik Bakımı}

HKHT hastaları uzun dönemde önemli ölçüde sosyal adaptasyonda zorlanmaktadırlar. Bunlar; aile ilişkileri, tekrar işe dönme ve cinsel ilişkiler olarak saptanmıştır. $^{34,36}$

\section{a. Cinsellik ve Hemşirelik Bakımı}

Cinsel aktivitedeki bozukluklar tipik olarak HKHT'den sonraki ilk 2 yıl içinde ortaya çıksa da, HKHT'den 5 ila 10 y1l sonra bile hastaların, cinsel işlev bozukluğu yaşadıkları görülmektedir. ${ }^{37}$ Nakil sonrası ilk yılda cinsel ilişkilerine devam eden bireyler uzun sürede daha az sorun yaşama eğilimindedirler. ${ }^{17}$ Erkeklerin yaklaşık yarısı, kadınların ise \%80'inin uzun süreli cinsel problemler yaşadıkları belirtilmiştir. $^{38}$

Hastanın cinsellikle ilgili konuları konuşabilmesi için firsatlar oluşturulmalıdır. Bu sürece hastanın partneri de eşlik etmelidir. Hasta cinsel yaşama uyum, yeterli ağrı / semptom kontrolü, cinsel yardım ve ilişkide rahat konumlandırma, doğum kontrolü, özel anlar sunma ve tıbbi tedavi hakkında bilgilendirilmelidir, desteklenmelidir ve rehberlik edilmelidir. Ayrıca hasta gevşeme, masaj terapisi ve aromaterapi gibi tedavilere yönlendirilebilir. ${ }^{17,38}$

\section{b. İşe Dönüş ve Hemşirelik Bakımı}

HKHT hastalarında işe geri dönüş iyileşmenin ve olumlu fonksiyonel durumun birincil göstergesidir. İşe geri dönmekte başarısız olanların fiziksel, bilişsel ve sosyal işlevleri zayıftır. Bu hastaların daha fazla ağrı, uyku bozukluğu ve sıkıntı rapor ettikleri bildirilmiştir. ${ }^{17,19,39}$ Yapılan çalışmalarda HKHT'den sonra tanıyı izleyen birkaç yıl içinde işe geri dönüş oranı \%55$\% 82$ arasında değişmektedir. ${ }^{19,39-41}$

Etkilenen sosyal sağlık alanlarını iyileştirmek için etkili rehabilitasyon stratejilerinin geliştirilmesi gerekmektedir. Ayrıca tüm HKHT hastaları periyodik olarak sosyal uyumsuzluk açısından taranmalıdır, hastalara kaynak ve sevk sağlanmalıdır. ${ }^{34}$

Hastanın güçlü yanları, sosyalleşme, başa çıkma becerileri değerlendirilmelidir ve geliştirilmelidir. Rol sorumluluklarının sürdürülmesi, başkaları ile terapötik etkileşimleri teşvik edilmelidir. Benlik saygısı, beden imajı, rol performansı ve kişisel kimlik duygularını paylaşması sağlanmalıdır. Durum, tedavi ve prognoz hakkında konuşması için teşvik edilmelidir. Hastanın uzun süreli takibi sağlanmalıdır. ${ }^{25,26,34}$

\section{c. Psikolojik Sıkıntı (Depresyon, Anksiyete) ve Hemşirelik Bakımı}

Her on kişiden dört HKHT hastası nakilden ortalama 3-4 yıl sonra psikolojik sıkıntı yaşamaktadır. ${ }^{17}$ Anksiyete ve depresyon gibi psikolojik sıkıntılar yaşam kalitesini ve iyileşmeyi olumsuz etkiler. ${ }^{1,42}$ Randevuları aksatma, kullanılmayan ya da fazla kullanılan ilaçlar, ileri tedavi ihtiyacı, depresyon, problem çözme zorluğu, istenen becerileri göstermede zorluk, hemşirelik ve /veya tıbbi tavsiyelere uymama şeklinde kendini gösterebilir. ${ }^{26}$ Dolayısıyla hemşirelerin, bu dönemde hastalarda gelişebilecek olası psikolojik sorunları ele alması, anksiyeteyi ve depresyonu önlemeye yönelik girişimlerin planlanması ve kademeli bakım uygulaması önemlidir. $^{42}$

Bilgiler zamanında ve özel bir şekilde sunulmalıdır. Hastanın gerekli bilgileri edinmesine yardımcı olunmalıdır. Pozitif çaba sarfedilmelidir. Hasta her ihtiyaç duyduğunda desteklenmelidir. Mümkün olduğunca öz bakımı teşvik edilmelidir. Hasta ve ailesi problem çözme sürecine dahil edilmelidir. Hastanın kaygıları saygıyla karşılanmalıdır ve bakımı sağlanmalıdır. Bağımlılığı teşvik eden yaklaşımların kullanılmasından kaçınılmalıdır. ${ }^{26,43}$

\section{5- Sekonder Malign Hastalıklar ve Hemşirelik Bakımı}

Sekonder malign hastalıklar HKHT'nin en ağır komplikasyonudur. Hastalar sekonder gelişim riski yönünden izlenmelidir. Hastaların kontrol sıklığının sağ kalımı arttırdığı belirtilmektedir. ${ }^{18,22} \mathrm{Bu}$ anlamda hem otolog hem de allojenik HKHT hastalarında nakil 


\section{Kök Hücre Transplantasyonunda Hemşirenin Rolü}

sonrası sağlık bakımı ile yaşam boyu sistematik takip yapilmalıdır. ${ }^{18,21}$

Hasta ve ailesi ikincil riskler konusunda bilgilendirilmelidir. Y1llik taramalar ve kendi kendine muayene yapma (örn. cilt, testis / genital bölge) teknikleri ögretilmelidir. Yüksek riskli davranışlardan kaçınmak için hastalar bilgilendirilmelidir. ${ }^{16,18}$

\section{6- Sistemlerle İlgili Komplikasyonlar ve Hemşirelik Bakımı}

a. Pulmoner Sistem: HKHT sonrası komplikasyonlar arasında idiyopatik pnömoni sendromu, bronşiyolit obliterans sendromu, kriptojenik organize pnömoni ve pulmoner enfeksiyonlar bulunur. 6 aylık ve yıllık fizik muayene ve öykü ile klinik değerlendirme yapılmalıdir.

Hastanın sigara içme öyküsü değerlendirilmelidir, sigara içen hastalara sigarayı bırakma konusunda danışmanlık verilmelidir. ${ }^{16,17,22}$

b. Kardiyovasküler Sistem: Kardiyak toksisite, otolog nakil hastalarının \%2'sinde ve allojenik nakil hastalarının \%3'ünde ölümden sorumludur. Fizik muayene, kan basıncı takibi, öykü ile 6 aylık ve yıllık klinik değerlendirme yapılmalıdır. Kardiyovasküler risk faktörlerinin erken tedavisinde diyabet, hipertansiyon ve dislipidemi gibi hasta, kardiyologa sevk edilmelidir. $^{16,17,18,21}$

Hastaya; sağlıklı yaşam tarzı, düzenli egzersiz yapma, sağlıklı kiloyu koruma, iyi beslenme ve sigara içmeme hususlarında danışmanlık verilmelidir. ${ }^{14,16,17}$

c. Renal ve Genitoüriner Sistem: Siklosporin, aminoglikozidler, asiklovir gibi birçok ilaç nefrotoksik olduğundan böbrek hasarı yaygındır; böbrek fonksiyonu 6 ayda ve daha sonra y1lda bir kez kontrol edilmelidir. Kronik böbrek hastalığı olan hastalar, nefrolojiye sevk edilmelidir, renal ultrason ve / veya biyopsi ile değerlendirme düşünülmelidir.

Hasta, hipertansiyon yönünden takip edilmelidir ve kan basıncı düzenli aralıklarla değerlendirilmelidir. $^{16,17,22}$

d. Kas İskelet Sistemi: Kas gücünün veya kas kütlesinin nakilden sonraki 6 ay içinde azaldığı, genellikle 5 y1l içinde iyileşmenin zor olduğu gözlemlenmiştir. ${ }^{1}$ Osteoporoz, 18 . ayda \%25-50 oranında görülmektedir. GVHD'li hastalar, özellikle sistemik steroid alan hastalar kas gücü, genel halsizlik ve işlev kaybı ile ilgili sorunlarla karşılaşabilir. Kemik dansitesi taramas1 endikedir. Korkitosteroid kullanan hastalar, myopati açısından değerlendirmedir. ${ }^{16,17,22}$

Hastaya düzenli günlük egzersiz önerilmelidir. Kemik mineral yoğunluğunu ve hasta düşmelerini önlemeyi optimize etmek için diyete ve egzersize yönelik hastya rehberlik yapılır. D vitamini ve kalsiyum takviyesi gerekebilir. GVHD geliştirenler, sklerotik değişiklikleri saptamak için eklem hareket aralığı açısından değerlendirilmelidir, aktif müdahale için fizyoterapiste yönlendirilmelidir.,16,17,22

e. Nörolojik Sistem: Hastaların \%20'sinde nöropsikolojik bozukluklar, \%10'ununda kognitif bozukluklar tanımlanmıştır. Hasta, uzun süreli kalsinörin inhibitörleri kullanımının bir sonucu olarak lökoensefalopati, bilişsel bozukluk veya nörotoksisite gibi nörolojik defisit semptomları açısından yıllık olarak değerlendirilmelidir. Ayrıca periferik nöropati belirtileri açısından da hasta taranmalıdır. Rutin değerlendirme sırasinda herhangi bir hasar bulunursa, hasta klinik bulgularda belirtildiği gibi sinir iletim çalıșmaları veya MRI için nörologa yönlendirilmelidir. ${ }^{\text {14,16,17,22 }}$

f. Endokrin Sistemi: Kök hücre naklinden sonra endokrin disfonksiyon yaygındır. Transplantasyondan sonraki ilk yılda hastaların \%7-15'inde yüksek TSH ve kompanse hipotiroidizm ortaya çıkar. TBI alan hastaların \%25'inde tiroid disfonksiyonu gelişmektedir. Tiroid fonksiyonu ve gonadal test yılda bir değerlendirilmelidir. Sonraki değerlendirmelerin sıklığı klinik ihtiyaçlara göre ele alınmalıdır. Hasta, durumuna göre hormon replasman tedavisi için endokrinologa yönlendirilmelidir. ${ }^{16,17,22}$

HKHT sonrası süreçte hastanın takibi yukarıda değinildiği gibi uzman bir ekiple gerçekleştirilir. Hasta; fiziksel, psikolojik, sosyal ve ekonomik tüm yönlerden değerlendirilir. ${ }^{5,22}$ HKHT hastasının bakımı, ilk tanı koyan ve tedavi eden hematologdan, sevk sonrası kronik takip bakımını yöneten ekiple devam ettirilmelidir. Ekipte; hematolog, hemşire, göz doktoru, odyolog, kardiyolog, fizyoterapist, konuşma terapisti ve psikiyatrist gibi branş uzmanları yer almaktadır. Karş1laşılan acil durumlarda hasta mutlaka ilgili birime yönlendirilmelidir. ${ }^{26,44,45}$ Standart uygulanan protokolün yanında (Tablo I) bireyselleştirilmiş bakımla, hasta sorunlarının erken dönemde çözümlenmesi sağlanacaktır. ${ }^{14,17}$

\section{Taburculuk Sonrası Süreçte Hemşirelerin Rolü}

Transplantasyondan sonraki ilk 2-5 yıl içinde remisyonda kalan hastalarda, takip eden 10 yılda yaklaşık \%80'inin ya da \%90'ının hayatta kalacağı bildirilmiştir. ${ }^{46}$ Destekleyici bakım çok önemlidir. Hemşire hasta bakımının merkezinde, hastaya ve aileye bu süreçte rehberlik etmek ve tavsiyede bulunmak için en iyi konumdadır. ${ }^{17,24}$ Hastalara verilen rehberlik, kısa vadeli ihtiyaçları yoluyla uzun vadeli hedeflere katkıda bulunmaktadır. ${ }^{47}$ Yapılan çalışmalarda HKHT yapılan hastaların taburculuk sonrası bakım ve eğitim ihtiyaçları olduğunu göstermektedir. ${ }^{7,48}$ 
Tablo I. Otolog ve allojenik HKHT sonrası geç komplikasyonların taranması ve önlenmesi ile ilgili öneriler ${ }^{16-18}$

\begin{tabular}{|c|c|}
\hline Sistemler & Taranma ve Önlenme İle İlgili Öneriler \\
\hline İmmünite & $\begin{array}{l}\text { Pneumocystis pnömoni profilaksisi } \\
\text { Nakil sonrası aşılama } \\
\text { Endokardit profilaksisi } \\
\text { GVHD'li hastalar* } \\
\text { Pneumocystis pnömoni ve kapsüllenmiş organizmalara karşı } \\
\text { profilaksi } \\
\text { Citomegalovirüs aktivasyonu için tarama }\end{array}$ \\
\hline Oküler & $\begin{array}{l}\text { Oküler komplikasyonlar için klinik değerlendirme } \\
\text { Oftalmolojik muayene } \\
\text { GVHD'li hastalar } \\
\text { Daha sık değerlendirme }\end{array}$ \\
\hline Oral & $\begin{array}{l}\text { Koruyucu ağız sağlığı uygulamaları hakkında eğitim } \\
\text { Oral komplikasyonlar için klinik oral değerlendirme } \\
\text { Diş muayenesi } \\
\text { GVHD'li hastalar } \\
\text { Daha sık değerlendirme } \\
\end{array}$ \\
\hline Solunum & $\begin{array}{l}\text { Sigarayı bırakma (varsa) } \\
\text { Pulmoner komplikasyonlar için klinik değerlendirme } \\
\text { GVHD'li hastalar } \\
\text { Daha sık klinik değerlendirme } \\
\end{array}$ \\
\hline $\begin{array}{l}\text { Kardiyak ve } \\
\text { vasküler }\end{array}$ & $\begin{array}{l}\text { Sağlıkı yaşam tarzı eğitimi, desteği } \\
\text { Kardiyovasküler risk faktörlerinin (örneğin diyabet) değerlendi- } \\
\text { rilmesi ve erken tedavisi } \\
\text { Endokardit profilaksisi }\end{array}$ \\
\hline Karaciğer & $\begin{array}{l}\text { Periyodik olarak karaciğer fonksiyon testleri değerlendirilmesi } \\
\text { Hepatit B veya C olduğu bilinen hastalarda viral yük izleme ve } \\
\text { karaciğer biyopsisi } \\
\text { Gerekirse } 1 \text { yılda serum ferritin (örneğin, MRI, karaciğer } \\
\text { biyopsisi) }\end{array}$ \\
\hline $\begin{array}{l}\text { Böbrek ve } \\
\text { genitoüriner }\end{array}$ & $\begin{array}{l}\text { Hipertansiyonun agresif tedavisi } \\
\text { Böbrek fonksiyonunun değerlendirilmesi }\end{array}$ \\
\hline $\begin{array}{l}\text { Kas ve bağ } \\
\text { dokusu }\end{array}$ & $\begin{array}{l}\text { Fiziksel aktiviteyi teşvik etme } \\
\text { GVHD veya uzun süreli steroid maruziyeti olan hastalar } \\
\text { Miyopati için klinik değerlendirme } \\
\text { Fizik tedavi konsültasyonu }\end{array}$ \\
\hline İskelet & $\begin{array}{l}\text { Fiziksel aktivite, D vitamini ve kalsiyum desteği teşviği } \\
\text { Yetişkin kadınlar, tüm allojenik nakiller ve yüksek kemik kaybı } \\
\text { riski taşıyan hastalar için } 1 \text { yılda çift foton dansitometrisi } \\
\text { GVHD veya uzun süreli steroid maruziyeti olan hastalar } \\
\text { Daha erken bir tarihte ikili foton dansitometrisi }\end{array}$ \\
\hline Sinir & $\begin{array}{l}\text { Nörolojik komplikasyonlar için klinik değerlendirme } \\
\text { Bilişsel gelişim için değerlendirme }\end{array}$ \\
\hline Endokrin & $\begin{array}{l}\text { Tiroid fonksiyon testi } \\
\text { Pubertal sonrası kadınlar için klinik ve endokrinolojik gonadal } \\
\text { değerlendirme } \\
\text { Erkeklerde gonadal fonksiyon değerlendirme } \\
\text { GVHD veya uzun süreli steroid maruziyeti olan hastalar } \\
\text { Steroidlerin yavaş yavaş kesilmesi } \\
\text { Akut hastalık sırasında steroidlerin stres doz tayini } \\
\text { Klinik ve endokrinolojik gonadal değerlendirme } \\
\text { Büyüme hızı izlemi }\end{array}$ \\
\hline $\begin{array}{l}\text { Mukokuta- } \\
\text { nöz }\end{array}$ & $\begin{array}{l}\text { Kendi kendine cilt muayenesi eğitimi ve güneş ışığına maruz } \\
\text { kalmayı en aza indirme } \\
\text { GVHD ve TBI** alan hastalar } \\
\text { Erken tutulumu tespit etmek için daha sık jinekolojik muayene }\end{array}$ \\
\hline $\begin{array}{l}\text { Sekonder } \\
\text { kanserler }\end{array}$ & $\begin{array}{l}\text { Hastalara sekonder kanser riskleri hakkında bilgi verme ve } \\
\text { yüksek riskli davranışlardan kaçındırma (Örn. sigara içmek) } \\
\text { Kanser taraması için genel popülasyon önerilerini takip etme } \\
\text { GVHD'li hastalar } \\
\text { Ağız ve yutak kanseri için değerlendirme } \\
\text { TBI ve göğüs ışınlaması alıcıları } \\
\text { Genel popülasyon önerilerinden daha erken yaşta kadınlarda } \\
\text { mamografi taraması }\end{array}$ \\
\hline $\begin{array}{l}\text { Psikososyal } \\
\text { ve cinsellik }\end{array}$ & $\begin{array}{l}\text { Klinik değerlendirme ve gerekirse ruh sağlı̆ı̆ı uzmanına sevk } \\
\text { Bakıcıyı / eşi psikolojik uyum ve aile işlevselliği için değerlen- } \\
\text { dirme } \\
\text { Cinsel işlev bozukluğu }\end{array}$ \\
\hline $\begin{array}{l}\text { Kadın } \\
\text { doğum }\end{array}$ & $\begin{array}{l}\text { Uygun uzmanlara yönlendirme } \\
\text { Doğum kontrolü }\end{array}$ \\
\hline
\end{tabular}

Tablo kullanımı için Majhail NS tarafından yazılı izin alınmıştır. ${ }^{16,18}$ ${ }^{*}$ CGVHD (Kronik graft versus host disease), **TBI (total body irradiation)
McKenna ve ark. (2015) ${ }^{49}$ tarafindan yapılan çalışmada HKHT yapılan hastaların taburcu olduktan sonraki 30 gün içinde 7'de 1 oranında tekrar kabul edildiği görülmüştür. Aynı çalışmada, 36 allojenik hastada 56 tekrar yatış görülürken, 23 otolog hastada 26 tekrar yatış saptanmıştır. Hastanın taburcu edilmeden önceki eğitiminin ve taburculuk sonrası nakil hemşiresi tarafindan sürekli eğitimlerin hastaneye tekrar yatışı azaltmada önemli olduğu vurgulanmıştır. ${ }^{47}$ Thomson ve ark. (2015) ${ }^{7}$ yaptıkları çalışmada HKHT ile ilgili profesyonel hemşirelik rollerinde (hemşire koordinatörü, vaka yöneticisi, yatan hasta hemşiresi) hasta geçişleri ile ilgili bir model oluşturarak hastaların hastanede kalış sürelerinin ve taburculuk sonrası yatış oranlarının azaldığını bildirilmiştir. Lepla ve ark. $(2020)^{9}$ tarafindan yapılan çalışmada ise HKHT hastalarında geçiş süreçlerinde boşluklar olduğu tespit edilmiştir. Çalışmada hastaların semptomları tanıma, anlama ve buna göre hareket etme konusunda güvensizlik içinde oldukları temalandırılmıştır.

Taburculuk sonrası erken bakım; ortaya çıkan komplikasyonların dikkatli değerlendirilmesini, enfeksiyonların önlenmesini ve erken tedavisini, sağlıklı beslenme durumunun yeniden oluşturulmasını, sürdürülmesini ve psikososyal desteği sağlamaktadır. ${ }^{10}$

Hemşireler bu süreçte;

$\checkmark$ Hastaların yararlanabileceği kaynakları belirlemelidir.

$\checkmark$ Hastalar için HKHT sonrası hizmetler geliştirmelidir (yüzyüze danışmanlık, elektronik semptom izleme, telefonla görüşme gibi).

$\checkmark$ Bakımın, hastanın ihtiyaçlarını ve endişelerini karşıladığından emin olmalıdır.

$\checkmark$ Bireysel pratik ve yenilikçi roller geliştirmelidir.

$\checkmark$ Hayatta kalma araştırmalarına liderlik ederek kanıt temelli bilgi geliştirmelidir ve kullanmalıdır.

$\checkmark$ Tedavi özeti ve hayatta kalma bakım planının uygulanması ve kullanımı için modeller geliştirmelidir.

$\checkmark$ Süreçte entegre, danışma, işbirlikçi ve geçiş bakım modellerini mutlaka kullanmalıdır.

$\checkmark$ Yaratıcı çalışma yolları geliştirmelidir.

$\checkmark$ Destekleyici bakım ve multidisipliner ekip anlayıŞını benimsemelidir. ${ }^{17-19,42,50,41,52,53}$

\section{Sonuç}

HKHT hastalarında nakil sonrası uzun süreli takip değerlidir. Bugüne kadar yapılan çalışmaların birçoğu sadece birkaç yıl hastaları takip etmiştir ve sistematik olarak yapılmamıştır. Kılavuzlar kullanılarak yapılan sistematik bakımla hemşirelerin, hastalarına etkin şekilde yardımcı olmaları sağlanacaktır. Hemşireler HKHT konusunda güncel kalmak ve özel eğitim al- 


\section{Kök Hücre Transplantasyonunda Hemşirenin Rolü}

mak için firsatlar aramalıdırlar. Bu konuda uzman hemşirelerin, hastaların fiziksel, psikososyal ve hayatta kalma ile ilgili süreçlerinde bilgilendirmeye, eğitime, dinamiklere ve kanıta dayalı müdahalelerle ihtiyaçlarını karşılayabilecekleri düşünülmektedir. Her ne kadar nakil hastalarında tarama ve önleyici uygulamalar son dönemde artmış olsa da, bu uygulamalar yetersizdir ve mutlaka daha fazlasına ihtiyaç vardır.

\section{Araştırmacı Katkı Beyanı:}

Fikir ve tasarım: H.K., F.A.; Veri toplama ve işleme: -; Analiz ve verilerin yorumlanması: -; Makalenin önemli bölümlerinin yazılmas1: H.K, F.A.

Destek ve Teşekkür Beyanı:

Bu çalıșmamıza finansal destek sağlanmamıștır.

Çıkar Catıșması Beyanı:

Makale yazarlarının çıkar çatışması beyanı yoktur.

\section{Kaynaklar}

1. Liang Y, Zhou M, Wang F, Wu Z. Exercise for physical fitness, fatigue and quality of life of patients undergoing hematopoietic stem cell transplantation: a meta-analysis of randomized controlled trials. Japanese Journal of Clinical Oncology. 2018;48(12):1046-57.

2. Laudenslager ML, Simoneau TL, Mikulich Gilbertson SK et al A randomized control trial of stress management for caregivers of stem cell transplant patients: effect on patient quality of life and caregiver distress. Psycho Oncology. 2019;28(8):1614-23.

3. Crooks M, Seropian S, Bai M, McCorkle R. Monitoring patient distress and related problems before and after hematopoietic stem cell transplantation. Palliative \& Supportive Care. 2014;12(1):53-61

4. Snowden JA, Saccardi R, Orchard K et al. Benchmarking of survival outcomes following haematopoietic stem cell transplantation: a review of existing processes and the introduction of an international system from the European Society for Blood and Marrow Transplantation (EBMT) and the Joint Accreditation Committee of ISCT and EBMT (JACIE). Bone Marrow Transplantation. 2020;55(4):681-94.

5. Cooke L, Grant M, Gemmill R. Patient-initiated discharge needs of allogeneic transplant patients. Clinical Journal of Oncology Nursing. 2012;16(4):142-9.

6. Zheng LY, Yuan H, Zhou ZJ et al. The role of spirituality in patients undergoing hematopoietic stem cell transplantation: a systematic mixed studies review. Journal of General Internal Medicine. 2020;1-16

7. Thomson B, Gorospe G, Cooke L, Giesie P, Johnson S. Transitions of care: A hematopoietic stem cell transplantation nursing education project across the trajectory. Clinical Journal of Oncology Nursing. 2015;19(4):74-9.

8. Mayer DK, Tighiouart $\mathrm{H}$, Terrin $\mathrm{N}$ et al. A brief report of caregiver needs and resource utilization during pediatric hematopoietic stem cell transplantation. Journal of Pediatric Oncology Nursing. 2009;26(4):223-9.

9. Leppla L, Mielke J, Kunze $\mathrm{M}$ et al. Clinicians and patients perspectives on follow-up care and eHealth support after allogeneic hematopoietic stem cell transplantation: a mixedmethods contextual analysis as part of the SMILe study. European Journal of Oncology Nursing. 2020;45:101723.

10. Grant M, Cook L, Williams AC et al. Functional status and health-related quality of life among allogeneic transplant patients at hospital discharge: a comparison of sociodemographic, disease, and treatment characteristics. Supportive Care in Cancer. 2012;20(11):2697-704.

11. Xie W, Zhang X, Wang J et al. Evaluation of quality of life and its influencing factors after transplantation of leukemia patients based on SF-36 score: a cohort study. Quality of Life Research. 2020;1-8.

12. Kurosawa S, Mori A, Tsukagoshi $\mathbf{M}$ et al. Current status and needs of long-term follow-up clinics for hematopoietic cell transplantation survivors: results of a nationwide survey in Japan. Biology of Blood and Marrow Transplantation. 2020;26:949-55.

13. de Azevedo IC, de Menezes RMP, de Medeiros SM et al. Hematopoietic stem cell transplantation based on the transdisciplinary care. International Archives of Medicine, 2016;9(28):1-6.

14. Bevans M, El-Jawahri A, Tierney DK et al. National Institutes of Health hematopoietic cell transplantation late effects initiative: the patient-centered outcomes working group report. Biology of Blood and Marrow Transplantation. 2017;23(4):538-51.

15. Kurosawa S, Tsukagoshi M, Munakata W et al. Cross-sectional patient survey on the need for a long-term follow-up program after autologous hematopoietic cell transplantation. Biology of Blood and Marrow Transplantation. 2016;22(3):189.

16. Majhail NS, Rizzo JD, Lee SJ et al. Recommended screening and preventive practices for long-term survivors after hematopoietic cell transplantation. Hematology/Oncology and Stem Cell Therapy. 2012;5(1):1-30.

17. Kenyon M, Murray J, Quinn B, Greenfield D, Trigoso E. Late effects and long-term follow-up. In: Kenyon M, Babic A (eds). The European blood and marrow transplantation textbook for nurses. London: Springer International Publishing. 2018. 271-300.

18. Battiwalla M, Tichelli A, Majhail NS. Long-term survivorship after hematopoietic cell transplantation: roadmap for research and care. Biology of Blood and Marrow Transplantation. 2017;23(2):184-92.

19. Heveran L, Andrewes T. Nursing measures to support the needs of haematological cancer survivors post-treatment: a literature review. British Journal of Nursing. 2020;29(3):18-24.

20. Atsuta Y, Hirakawa A, Nakasone $\mathrm{H}$ et al. Late mortality and causes of death among long-term survivors after allogeneic stem cell transplantation. Biology of Blood and Marrow Transplantation. 2016;22(9):1702-9.

21. Battiwalla M, Hashmi S, Majhail N et al. National Institutes of Health Hematopoietic Cell Transplantation late effects initiative: developing recommendations to improve survivorship and long-term outcomes. Biology of Blood and Marrow Transplantation. 2017;23(1):6-9.

22. Majhail NS. Long-term complications after hematopoietic cell transplantation. Hematology/Oncology and Stem Cell Therapy. 2017;10(4):220-7.

23. Mitchell SA, Leidy NK, Mooney KH et al. Determinants of functional performance in long-term survivors of allogeneic hematopoietic stem cell transplantation with chronic graftversus-host disease (cGVHD). Bone Marrow Transplantation. 2010;45(4):762-9.

24. Murray J, Stringer J, Hutt D. Graft Versus Host Disease (GvHD) In: Kenyon M, Babic A (eds). The European blood and marrow transplantation textbook for nurses. London: Springer International Publishing. 2018. 221-52.

25. Neumann J. Nursing challenges caring for bone marrow transplantation patients with graft versus host disease. Hematology/Oncology and Stem Cell Therapy. 2017;10(4):192-4.

26. Mitchell SA. Acute and Chronic Graft Versus Host Disease. In: Ezzone SA (eds). Hematopoietic Stem Cell Transplantation: A Manual for Nursing Care. 2 nd ed. Oncology Nursing Society. 2013. 103-54. 


\section{H. Kara ve F. Arıkan}

27. Mattson MR. (2007). Graft-versus-host disease: review and nursing implications. Clinical Journal of Oncology Nursing. 2007;11(3):325-8.

28. Woods AM. Daily routines and guidelines: driving, infection isolation, masks, food/diet, activities, exercise, pets, sun exposures, and others. In: Savani BN (eds). Blood and Marrow Transplantation Long-term Management: Prevention and Complications. John Wiley \& Sons. 2013. 332-9.

29. Peric Z, Botti S, Stringer J et al. Variability of nutritional practices in peritransplant period after allogeneic hematopoietic stem cell transplantation: a survey by the Complications and Quality of Life Working Party of the EBMT. Bone Marrow Transplantation. 2018;53(8):1030-7.

30. Zatarain L, Hill LQ, Thomas DR, Goodman SA. Nutritional assessments and nutritional supplementation for long-term transplant survivors: multivitamins, vitamin D, calcium, antioxidants, and minerals. In: Savani BN (eds). Blood and Marrow Transplantation Long-term Management: Prevention and Complications. John Wiley \& Sons. 2013. 323-31.

31. van der Linden SJ, Harinck MEG, Speksnijder HT et al. Supportive Care. In: Kenyon M, Babic A (eds). The European blood and marrow transplantation textbook for nurses. London: Springer International Publishing. 2018. 197-220.

32. Wallhult E, Quinn B. Early and acute complications and the principles of HSCT nursing care. In: Kenyon M, Babic A (eds). In The European blood and marrow transplantation textbook for nurses. Springer International Publishing. 2018. 163-95.

33. Baer LK, Weinstein E, Daly B et al. Stem cell transplant and palliative care: joining forces to improve survivor quality of life. Biology of Blood and Marrow Transplantation. 2020;26(3):357.

34. Park J, Wehrlen L, Mitchell SA, Yang L, Bevans MF. Fatigue predicts impaired social adjustment in survivors of allogeneic hematopoietic cell transplantation (HCT). Supportive Care in Cancer. 2019;27(4):1355-63.

35. Baydoun M, Barton DL. (2018). Complementary therapies for fatigue after hematopoietic stem cell transplantation: an integrative review. Bone Marrow Transplantation. 2018;53(5):556-64.

36. Pidala J, Anasetti C, Jim H. Health related quality of life following haematopoietic cell transplantation: patient education, evaluation and intervention. British Journal of Haematology. 2010;148(3):373-85.

37. Niscola P, Efficace F, Abruzzese E. Sexual health in patients with hematological malignancies: a neglected issue. Supportive Care in Cancer. 2018;26(6):1699-701.

38. Syrjala KL, Kurland BF, Abrams JR, Sanders JE, Heiman JR Sexual function changes during the 5 years after high-dose treatment and hematopoietic cell transplantation for malignancy, with case-matched controls at 5 years. Blood, The Journal of the American Society of Hematology. 2008;111(3):989-96.

39. Kirchhoff AC, Leisenring W, Syrjala KL. Prospective predictors of return to work in the 5 years after hematopoietic cell transplantation. Journal of Cancer Survivorship. 2010;4(1):3344.
40. Winterling J, Johansson E, Wennman-Larsen A et al. Occupational status among adult survivors following allo SCT. Bone Marrow Transplantation. 2014;49(6):836-42.

41. Morrison EJ, Ehlers SL, Bronars CA et al. Employment status as an indicator of recovery and function one year after hematopoietic stem cell transplantation. Biology of Blood and Marrow Transplantation. 2016;22(9):1690-5.

42. Braamse AM, van Meijel B, Visser O et al. Distress and quality of life after autologous stem cell transplantation: a randomized clinical trial to evaluate the outcome of a web-based stepped care intervention. BMC Cancer, 2010;10(1):361.

43. Koll TT, Semin JN, Coburn RA et al. Returning to life activities after hematopoietic cell transplantation in older adults. Journal of Geriatric Oncology. 2020;11(2):304-10.

44. Shah GL, Majhail N, Khera N, Giralt S. Value-based care in hematopoietic cell transplantation and cellular therapy: challenges and opportunities. Current Hematologic Malignancy Reports. 2018;13(2):125-134.

45. Guffon N, Pettazzoni M, Pangaud N et al. Long term disease burden post-transplantation: three decades of observations in 25 Hurler patients successfully treated with hematopoietic stem cell transplantation (HSCT). Orphanet Journal of Rare Diseases. 2021;16(1):1-20.

46. Majhail NS, Tao L, Bredeson C et al. Prevalence of hematopoietic cell transplant survivors in the United States. Biology of Blood and Marrow Transplantation. 2013;19(10):1498-501.

47. Barban A, Coracin FL, Musqueira PT et al. (2014). Analysis of the feasibility of early hospital discharge after autologous hematopoietic stem cell transplantation and the implications to nursing care. Revista Brasileira de Hematologia e Hemoterapia. 2014;36(4):264-8.

48. Brown M. Nursing care of patients undergoing allogeneic stem cell transplantation. Nursing Standard. 2010;25(11):47-56.

49. McKenna DR, Sullivan MR, Hill JM et al. Hospital readmission following transplantation: identifying risk factors and designing preventive measures. The Journal of Community and Supportive Oncology. 2015;13(9):316-22.

50. Hashmi SK, Bredeson C, Duarte RF et al. National institutes of health blood and marrow transplant late effects initiative: the healthcare delivery working group report. Biology of Blood and Marrow Transplantation. 2017;23(5):717-25.

51. Shaw BE, Hahn T, Martin PJ et al. National institutes of health hematopoietic cell transplantation late effects initiative: the research methodology and study design working group report. Biology of Blood and Marrow Transplantation. 2017;23(1):10-23.

52. Fauer AJ, Hoodin F, Lalonde L et al. Impact of a health information technology tool addressing information needs of caregivers of adult and pediatric hematopoietic stem cell transplantation patients. Supportive Care in Cancer. 2019;27(6):2103-12.

53. Bryant AL, Coffman E, Phillips B et al. Pilot randomized trial of an electronic symptom monitoring and reporting intervention for hospitalized adults undergoing hematopoietic stem cell transplantation. Supportive Care in Cancer. 2020;28(3):122331. 